\title{
Resistance and Virulence Features in Carbapenem-resistant Acinetobacter baumannii Community Acquired and Nosocomial Isolates in Romania
}

\author{
IRINA GHEORGHE ${ }^{1,2}$, VIOLETA CORINA CRISTEA ${ }^{3,4 *}$, LUMINITA MARUTESCU1,2, MARCELA POPA ${ }^{1,2}$, CARMEN MURARIU5, \\ BIANCA SIMONA TRUSCA ${ }^{6}$, ELVIRA BORCAN ${ }^{6}$, MIHAIELA CAMELIA GHITA, VERONICA LAZAR ${ }^{1,2,}$ \\ MARIANA CARMEN CHIFIRIUC 1,2 \\ ${ }^{1}$ University of Bucharest, Faculty of Biology, Department of Microbiology and Immunology, 36-46 Kogalniceanu Blvd., Bucharest, \\ Romania \\ ${ }^{2}$ Research Institute of the University of Bucharest (ICUB), 4-12 Regina Elisabeta Blvd., 030018, Bucharest, Romania \\ ${ }^{3}$ Synevo Central Laboratory, Medicover, 25 Industriilor Str, Chiajna, Romania \\ ${ }^{4}$ University of Medicine and Pharmacy Carol Davila, 88 Mircea Vulcanescu Str., 01082, Bucharest, Romania \\ ${ }^{5}$ Emergency Hospital for Children Marie S. Curie, 20 Constantin Brancoveanu Blvd., 077120, Bucharest, Romania \\ ${ }^{6}$ Fundeni Hospital, 258 Fundeni Road, 022322, Bucharest, Romania
}

\begin{abstract}
We aimed to identify the virulence and antimicrobial resistance features in Carbapenem Resistant Acinetobacter baumannii (CRAB) strains isolated from hospital settings and compare them with those isolated in the same period of time from community acquired (CA) infections in Bucharest, south of Romania. A total number of $93 \mathrm{~A}$. baumannii strains were isolated in majority from hospitalized patients and from CA infections. The resistance and virulence mechanisms of the strains were characterized by phenotypic and genotypic methods. The antibiotic resistance profiles in $H$ and CA A. baumannii isolates revealed high percentages of carbapenem-resistance in both $\mathrm{H}$ and $C A$ isolates. The ciprofloxacin resistance was found very closed in both types of isolates (84\%/83.33\%). CRAB $H$ and CA isolates revealed the intrinsec carbapenemase OXA-5land the acquired carbapenemases OXA-23, OXA-24, IMP,and VIM-2. The bla gene was identified in different plasmid types (GR2-Aci1, GR6-pACICU2). rep135040, p3S18 and Aci6 in $\mathrm{A}$ A. baumannii isolates. The most frequently expressed virulence factor was lipase and DN-ase. OXA-51-like alleles corresponding to the two main sequence groups were identified as bla ${ }_{0 x a 66}$ (63.63\% of the isolates) and respectively, bla ${ }_{\text {oxa-69 }}(38.39 \%)$ and revealed the corresponding type of ompAand csuE sequence grouping. AphA6 (24\%/16.6\%), AphA1 (16\%/16.6\%) and aadB (9.3\%/5.5\%) genes were responsible for aminoglycosides resistance. Our survey revealed a high drug resistance in $A$. baumannii isolates. Different plasmid groups containing CRAB isolates may facilitate the bla ${ }_{0 \times A 23}$ dissemination.
\end{abstract}

Keywords: carbapenem resistance, virulence, community acquired, nosocomial infections

Acinetobacter baumannii is recognized as an opportunistic nosocomial pathogen, mainly in immunocompromised patients being frequently associated with therapeutic failures, due to its multi-drug (MDR), extended-drug (XDR) or even pan-drug resistance (PDR) phenotypes. Carbapenems were the antibiotics of choice for infections treatment caused by this organism, butresistance to carbapenems is becoming common, and very few therapeutic options remain. Mortality rates associated with Carbapenem Resistant Acinetobacter baumannii (CRAB) isolates are steadily growing at present $[1,2]$. In $A$. baumannii clinical isolates five groups of acquired, chromosomal or plasmid located CHDLs (class $D \beta$-lactamases) with variable geographic distribution have been identiûed, i.e.: OXA-23, OXA-24/-40, OXA-58, OXA143 and OXA-235 [3]. OXA-23 is the most worldwide distributed enzyme in $A$. baumannii, having been implicated in outbreaks in multiple European (including Romania and other Eastern European countries), Asian and American countries and Oceania [4-6]. There have been revealed that overexpression of the bla $a_{\text {pxa-5t-like }}$ gene intrinsic in $A$. baumannii was responsible for carbapenem resistance. The overexpression is due to the acquisition of a promoter provided by an insertion sequence (IS) element, ISAbaI, inserted upstream of the carbapenemase gene [7].
The acquisition of genes encoding aminoglycosidemodifying enzymes (AMEs) has been a main cause of resistance to aminoglycosides in $A$. baumannii [8]. Different AME-encoding genes, such as aphA1, aphA6, aphA15, aacC1, aacC2, aacA4, aadB, aadA1, and $\operatorname{aad} A 4$, have been detected in clinical isolates of $A$. baumannii $[8,9]$. Many of these genes (for example, aac $C 1$, aacA4, and aadA1) are located on class 1 integrons [10]. In contrast, the aphA1 and aphA6 genes have always been surrounded by IS elements, forming different composite transposon structures [7].

Numerous potential virulence factors have been revealed in $A$. baumannii strains, including biofilm formation [several factors contribute to biofilm formation such as the Csu pili [11] encoded by csuE gene, the autoinducer synthase $A b a l$, part of the quorum sensing (QS) system [12], the outer membrane protein A (encoded by OmpA gene) which facilitates the adhesion to host epithelial cells], complement resistance [13], iron acquisition characteristics, capsule, outer membrane protein phospholipases, alteration in penicillin-binding proteins [14]. Phospholipases $C$ and $D$ are responsible for epithelial cell invasion [15, 16]; the siderophore acinetobactin [17]; the polysaccharidic capsule [18]; and a penicillin-binding protein 7/8 [19] are important for 
survival and dissemination in human serum. Growth in serum has been demonstrated to upregulate iron acquisition systems, genes associated with epithelial cell adherence and DNA uptake, as well as numerous putative antibiotic efflux pumps, leading to increased antibiotic tolerance [20]. In addition, lipopolysaccharide (LPS) is an important cell envelope component, which influence the pathogenic potential of $A$. baumannii by the 0 polysaccharide chain (0-antigen) [21].

Regarding $A$. baumannii infections the most predisposed are patients from ICU in which this pathogen may cause serious infection and, thus, contributes substantially to the considerable mortality of this population [22]. Although the attention of $A$. baumannii infections has been focused on hospitalized patients, there is another patient population that may be affected by this important pathogen, namely, patients in the community setting that have some form of morbidity, especially in the tropical and sub-tropical area [23].

Originally, we are interested in identifying the relationship between virulence and antimicrobial resistance in $C R A B$ strains from both hospital settings and the community, the ARGs, their transfer and dissemination into the community.

\section{Experimental part}

\section{Material and methods}

The study included 93 recently isolated (Aug-Nov 2017) A. baumanniistrains, which were isolated in majority from hospitalized patients $(H)(n=75)$ and from CA infections $(n=18)$. The hospital strains were identified by BD Phoenix and the CA ones by mass spectrometry using MALDI Biotyper and MicroScan Walk Away 96. Carbapenemases and virulence genes were searched by PCR.

Antibiotic resistance

The antibiotic susceptibility was determined by KirbyBauer standard disk diffusion method [using the antibiotics recommended by CLSI, 2017: meropenem (MEM), imipenem (IMP), ertapenem (ETP), cephalotin (CEF) ceftriaxon (CTX), cefuroxime (CXM), cefoxitin (FOX), ceftazidim (CAZ), aztreonam (ATM), cefepime (FEP), amoxicillin-clavulanic acid (AMC), piperacilin-tazobactam (PIP-TZP), ciprofloxacin (CIP), levofloxacin (LEV) gentamycin (GEN), amikacin (AMK), nitrofurantoin (NIT), trimethoprim-sulfamethoxazole (SXT), tetracycline (TET), tigecycline (TIG) and colistin] and quality control was performed with Pseudomonas aeruginosa ATCC 27853 and automated methods (BD Phoenix and Vitek II).

\section{Evaluation of the soluble enzymatic factors}

The virulence phenotypes were investigated by performing enzymatic tests for the expression of the following soluble virulence factors: haemolysins, pore forming toxins (lecithinase, lipase), proteases (caseinase, gelatinase), amylase and aesculin hydrolysis.

\section{Genetic support of $A R$ and virulence in CRAB}

The genetic support of the resistance (carbapenemases and aminoglycosides table 1), Plasmid analysis included identification of replicase genes:19 PCR amplifications were devised to detect 27 replicase genes, which were grouped into 19 homology groups (GRs) on the basis of their nucleotide sequence similarities (table 2), BIOPFILM biofilm producing virulence factors (table 3 ) and global lineage in CRAB (table 4) was investigated by simplex and multiplex PCR, using a reaction mix of $20 \mu \mathrm{L}$ (PCR Master Mix 2X, Thermo Scientific) containing $1 \mu \mathrm{L}$ of bacterial DNA extracted using the alkaline extraction method. In this purpose, 1-5 colonies of bacterial cultures were suspended in $1.5 \mathrm{ml}$ tubes containing $20 \mu \mathrm{L}$ solution of $\mathrm{NaOH}$ (sodium hydroxide) and SDS (sodium dodecyl sulphate). The following step was the addition of $180 \mu \mathrm{L}$ of TE buffer (TRIS+EDTA) $1 X$ and centrifugation at $13000 \mathrm{rpm}$ for 3 min. All PCR reactions were performed using the Thermal Cycler machine Bio-Rad.

Table 1

THE TARGET GENES SCREENED FOR CARBAPENEMASES AND AMINOGLYCOSIDES

\begin{tabular}{|c|c|c|c|c|}
\hline Target gene & Primer name & Sequence & $\begin{array}{l}\text { Amplicon size } \\
\text { (bp) }\end{array}$ & Reference \\
\hline bla $0 \times 4 \cdot 22$ & $\begin{array}{l}\text { OXA-23-F } \\
\text { OXA-23-R }\end{array}$ & $\begin{array}{l}\text { 5'-ATGAGTTATCTATTTTTGTC-3' } \\
\text { 5'-TGTCAAGCTCTTA_AATAATA-3' }\end{array}$ & 501 & [24] \\
\hline bla $a_{0 x+2.24}$ & $\begin{array}{l}\text { OXA24/40-F } \\
\text { OXA2 } 24 / 40-R\end{array}$ & $\begin{array}{c}5^{\prime} \\
\text { GCAGAAAGAAGTAAARCGGGT3' } \\
5^{\prime} \text { CCAACCWWTCA_ACCAACCTA3, }\end{array}$ & 270 & [25] \\
\hline bla $a_{0 x} \cdot 51$ & $\begin{array}{l}\text { OXA-51-F } \\
\text { OXA-51-R }\end{array}$ & $\begin{array}{l}\text { 5'-TAATGCTTTGATCGGCCTTG-3' } \\
\text { 5'-TGGATTGCACTTCATCTTGG-3' }\end{array}$ & 353 & [24] \\
\hline bla $a_{0 x a} \cdot 58$ & $\begin{array}{l}\text { OXA-58-F } \\
\text { OXA-58-R }\end{array}$ & $\begin{array}{l}\text { 5'-AAGTATTGGGGCTTGTGCTG-3' } \\
\text { 5'-CCCCTCTGCGCTCTACATAC-3' }\end{array}$ & 599 & {$[24$} \\
\hline bla $a_{0 \times-14}$ & $\begin{array}{l}\text { OXA-143-F } \\
\text { OXA-143-R }\end{array}$ & $\begin{array}{l}\text { 5'-TGGATTGCACTTCATCTTGG-3', } \\
\text { 5'-TGGCACTTTCAGCAGTCCT-3' }\end{array}$ & 180 & [26] \\
\hline bla $a_{0 \times 1.135}$ & $\begin{array}{l}\text { OXA-235-F } \\
\text { OXA-235-R }\end{array}$ & $\begin{array}{l}\text { 5'-TTGTTGCCTTTACTTAGTTGC-3' } \\
\text { 5'-CAAAATTTAAAGACGGATCG-3' }\end{array}$ & 700 & [26] \\
\hline$b l a_{\mathrm{n}} \theta$ & $\begin{array}{l}\text { blaIMP-F } \\
\text { blalMP-R }\end{array}$ & $\begin{array}{l}\text { GGAATAGAGTGGCTTAAYTCTC } \\
\text { GGTTTAAYAAAACAACCACC }\end{array}$ & 232 & [25] \\
\hline blaviM-2 & $\begin{array}{l}\text { blaVIM }-2-\mathrm{F} \\
\text { blaVIM-2-R }\end{array}$ & $\begin{array}{l}\text { GATGGTGTTTGGTCGCATA } \\
\text { CGAATGCGCAGCACCAG }\end{array}$ & 800 & [27] \\
\hline \multirow{6}{*}{ AME's } & $\begin{array}{l}\text { aphA6-F } \\
\text { aphA6-R }\end{array}$ & $\begin{array}{l}\text { ATGGAATTGCCCAATATTATTC } \\
\text { TCAATTCAATTCATCAAGTTTTA }\end{array}$ & 797 & \multirow[t]{6}{*}{ [26] } \\
\hline & $\begin{array}{l}\text { aphAl-F } \\
\text { aphAl-R }\end{array}$ & $\begin{array}{l}\text { CAACGGGAAACGTCTTGCTC } \\
\text { ATTCGTGATTGCGCCTGAG }\end{array}$ & 455 & \\
\hline & aacA4-F & $\begin{array}{l}\text { ATGACTGAGCATGACCTTGCG } \\
\text { TTAGGCATCACTGCGTGTCG }\end{array}$ & 518 & \\
\hline & $\begin{array}{l}\text { aadB-F } \\
\text { aadB-R }\end{array}$ & $\begin{array}{l}\text { ATGGACACAACGCAGGTCGC } \\
\text { TTAGGCCGCATATCGCGACC }\end{array}$ & 524 & \\
\hline & $\begin{array}{l}\text { aadAl-F } \\
\text { aadAl-R }\end{array}$ & $\begin{array}{l}\text { ATGAGGGAAGCGGTGATCG } \\
\text { TTATTTGCCGACTACCTTGGTG }\end{array}$ & 254 & \\
\hline & $\begin{array}{l}\operatorname{aacCl}-\mathrm{F} \\
2 a r \mathrm{Cl}_{-} \mathrm{R}\end{array}$ & $\begin{array}{l}\text { ATGGGCATCATTCGCACATGTAGG } \\
\text { TTAGGTGGCGGTACTTGGGTC }\end{array}$ & 456 & \\
\hline
\end{tabular}




\begin{tabular}{|c|c|c|c|c|}
\hline Target gene & Primer name & Sequence & $\begin{array}{l}\text { Amplicon size } \\
\text { (bp) }\end{array}$ & Reference \\
\hline $\begin{array}{c}\text { Grl } \\
\text { (plABSDF001) }\end{array}$ & $\begin{array}{l}\text { grl-F } \\
\text { grl-R }\end{array}$ & $\begin{array}{l}\text { 5'-CATAGAAATACAGCCTATAAAG-3' } \\
\text { 5'-TTCTTCTAGCTCTACCAAAAT- } 3^{\prime}\end{array}$ & 330 & {$[28]$} \\
\hline $\begin{array}{c}\mathrm{GR2} \\
(\mathrm{Acil} / \mathrm{Aci} 2)\end{array}$ & $\begin{array}{l}\text { gr2-F } \\
\text { gr2-R }\end{array}$ & $\begin{array}{c}\text { 5'-AGTAGAACAACGTTTAATTTTATTGGC-3' } \\
\text { 5'-CCACTTTTTTAGGTATGGGTATAG-3 }\end{array}$ & 851 & \\
\hline $\begin{array}{c}\text { GR3 } \\
\text { (Aci3/Aci7) }\end{array}$ & $\begin{array}{l}\text { gr3-F } \\
\text { gr3-R }\end{array}$ & $\begin{array}{l}\text { 5'-TAATTAATGCCAGTTATAACCTTG-3 } \\
\text { 5'-GTATCGAGTACACCTATTTTTTGT-3' }\end{array}$ & 505 & \\
\hline $\begin{array}{l}\text { GR4 } \\
\text { (Aci4) }\end{array}$ & $\begin{array}{l}\text { gr4-F } \\
\text { gr4-R }\end{array}$ & $\begin{array}{l}\text { 5'-GTCCATGCTGAGAGCTATGT-3' } \\
\text { 5'-TACGTCCCTTTTATGTTGC-3' }\end{array}$ & 508 & \\
\hline $\begin{array}{l}\text { GR5 } \\
\text { (Aci5) }\end{array}$ & $\begin{array}{l}\text { gr5-F } \\
\text { gr5-R }\end{array}$ & $\begin{array}{l}\text { 5'-AGAATGGGGAACTTTAAAGA-3' } \\
\text { 5'-GACGCTGGGCATCTGTTAAC-3' }\end{array}$ & 220 & \\
\hline $\begin{array}{c}\text { GR6 } \\
\text { (Aci6) }\end{array}$ & $\begin{array}{l}\text { gr6-F } \\
\text { gr6-R }\end{array}$ & $\begin{array}{l}\text { 5'-AGCAAGTACGTGGGACTAAT-3' } \\
\text { 5'-AAGCAATGAAACAGGCTAAT-3' }\end{array}$ & 662 & \\
\hline $\begin{array}{c}\text { GR7 } \\
\text { (p3ABSDF002) }\end{array}$ & $\begin{array}{l}\text { gr7-F } \\
\text { gr } 7-R\end{array}$ & $\begin{array}{l}\text { 5'-GAACAGTTTAGTTGTGAAAG- }^{\prime} 3^{\prime} \\
5^{\prime} \text {-TCTCTAAATTTTCAGGCTC- } 3^{\prime}\end{array}$ & 885 & \\
\hline $\begin{array}{c}\text { GR8 } \\
{[\text { Aci\&, repM (Aci9)] }}\end{array}$ & $\begin{array}{l}\text { gr8-F } \\
\text { gr8-R }\end{array}$ & $\begin{array}{c}5^{\prime} \text {-AATTAATCGTAAAGGATAATGC- }-3^{\prime} \\
5^{\prime} \text {-GACATAGCGATCAAATAAGC-3' }\end{array}$ & 233 & \\
\hline $\begin{array}{c}\text { GR9 } \\
\text { (p3ABSDF0009) }\end{array}$ & $\begin{array}{l}\text { gr9-F } \\
\text { gr9-R }\end{array}$ & $\begin{array}{l}\text { 5'-GCAAGTTATACATTAAGCCT-3' } \\
\text { 5'-AAAAATAAACGCTCTGATGC-3' }\end{array}$ & 191 & \\
\hline $\begin{array}{l}\text { GRl0 } \\
(\text { AciX })\end{array}$ & $\begin{array}{l}\text { grl0-F } \\
\text { grlo-R }\end{array}$ & $\begin{array}{l}\text { 5'-TTTCACTAGCTACCAACTAA-3' } \\
\text { 5'-ACACGTTGGTTTGGAGTC-3' }\end{array}$ & 371 & \\
\hline $\begin{array}{c}\text { GRl1 } \\
\text { (plABAYE0001) }\end{array}$ & $\begin{array}{l}\text { grll-F } \\
\text { grll-R }\end{array}$ & $\begin{array}{c}\text { 5'-GGCTATTCAAAACAAAGTTAC-3' } \\
\text { 5'-GTTTCCTCTCTTACACTTTT-3' }\end{array}$ & 852 & \\
\hline $\begin{array}{c}\text { GR12 } \\
(\mathrm{p} 2 \mathrm{ABSDF} 0001)\end{array}$ & $\begin{array}{l}\text { grl2-F } \\
\text { gr } 12-\mathrm{R}\end{array}$ & 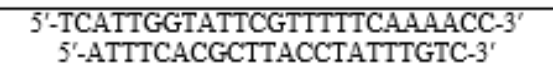 & 165 & \\
\hline $\begin{array}{c}\text { GR13 } \\
(\mathrm{p} 3 \mathrm{ABAYE0002)}\end{array}$ & $\begin{array}{l}\text { grl3-F } \\
\text { grl3-R }\end{array}$ & $\begin{array}{c}\text { 5'-CAAGATCGTGAAATTACAGA-3' } \\
\text { 5'-CTGTTTATAATTTGGGTCGT-3' }\end{array}$ & 780 & \\
\hline $\begin{array}{c}\text { GR14 } \\
\text { (p4ABAYE0001) }\end{array}$ & $\begin{array}{l}\text { grl4-F } \\
\text { grl4-R }\end{array}$ & $\begin{array}{l}\text { 5'-TTAAATGGGTGCGGTAATTT-3' } \\
\text { 5'-GCTTACCTTTCAAAACTTTG-3' }\end{array}$ & 622 & \\
\hline $\begin{array}{c}\text { GR15 } \\
\text { (p3ABSDF0018) }\end{array}$ & $\begin{array}{l}\text { grl5-F } \\
\text { grl5-R }\end{array}$ & $\begin{array}{l}\text { 5'-GGAAATAAAAATGATGAGTCC-3' } \\
\text { 5'-ATAAGTTGTTTTTGTGTATTCG-3' }\end{array}$ & 876 & \\
\hline $\begin{array}{c}\text { GR16 } \\
\text { (repApAB49) }\end{array}$ & $\begin{array}{l}\text { grl6-F } \\
\text { grl6-R }\end{array}$ & $\begin{array}{l}\text { 5'-CTCGAGTTCAGGCTATTTTT-3' } \\
\text { 5'-GCCATTTCGAAGATCTAAAC-3' }\end{array}$ & 233 & \\
\hline $\begin{array}{c}\text { GR17 } \\
\text { (Als_3471) }\end{array}$ & $\begin{array}{l}\text { grl7-F } \\
\text { grl7-R }\end{array}$ & $\begin{array}{l}\text { 5'-AATAACACTTATAATCCTTGTA-3' } \\
\text { 5'-GCAAATGTGACCTCTAATATA-3' }\end{array}$ & 380 & \\
\hline $\begin{array}{c}\text { GRi18 } \\
\text { (p2ABSDF00025) }\end{array}$ & $\begin{array}{l}\text { grl8-F } \\
\text { grl8-R }\end{array}$ & $\begin{array}{l}\text { 5'-TCGGGTTATCACAATAACAAA-3' } \\
\text { 5'-TAGAACATTGGCAATCCATA-3' }^{\prime}\end{array}$ & 676 & \\
\hline $\begin{array}{c}\text { GR19 } \\
\text { (repl35040) }\end{array}$ & $\begin{array}{l}\text { grl9-F } \\
\text { grl9-R }\end{array}$ & $\begin{array}{l}5^{\prime} \text { - ACGAGATACAAACATGCTCA-3' } \\
5^{\prime} \text { - AGCTAGACATTTCAGGCATT- } 3^{\prime}\end{array}$ & 815 & \\
\hline
\end{tabular}

Table 2

PRIMERS USED TO DETECT THE REPLICASE GENE GROUPS IN THE $A$. Baumannii PCR-BASED REPLICON TYPING SCHEME

\begin{tabular}{|c|c|c|c|c|}
\hline Target gene & Primer name & Sequence & $\begin{array}{l}\text { Amplicon size } \\
\text { (bp) }\end{array}$ & Reference \\
\hline \multirow{2}{*}{$\begin{array}{l}\text { Biofilm } \\
\text { producing } \\
\text { virulence } \\
\text { factors }\end{array}$} & $\begin{array}{l}\text { ompA-F } \\
\text { ompA-R }\end{array}$ & $\begin{array}{l}\text { 5'- CGCTTCTGCTGGTGCTGAAT -3' } \\
\text { 5'- CGTGCAGTAGCGTTAGGGTA -3' }\end{array}$ & 531 & \multirow[t]{2}{*}[26]{} \\
\hline & $\begin{array}{l}\text { epsA-R } \\
\text { epsA-R }\end{array}$ & $\begin{array}{l}5^{\prime} \text { - AGCAAGTGGTTATCCAATCG-3' } \\
5^{\prime} \text { - ACCAGACTCACCCATTACAT-3, }\end{array}$ & 451 & \\
\hline
\end{tabular}

Table 3

INVESTIGATED BIOFILM PRODUCING VIRULENCE FACTORS

\begin{tabular}{|c|c|c|c|}
\hline \multicolumn{3}{|c|}{ Multiplex 1} & \multirow[b]{2}{*}{ Reference } \\
\hline Primer & Sequence & $\begin{array}{l}\text { Amplicon } \\
\text { Size (bp) }\end{array}$ & \\
\hline GrouplompAF306 & 5'-GATGGCGTAAATCGTGGTA-3' & \multirow[t]{2}{*}{355} & \multirow[t]{13}{*}{ [29] } \\
\hline Groupland2ompAR660 & 5'-CAACTTTAGCGATTTCTGG-3' & & \\
\hline GrouplcsuEF & 5'-CTTTAGCAAACATGACCTACC-3' & \multirow[t]{2}{*}{702} & \\
\hline GrouplcsuER & 5'-TACACCCGGGTTAATCGT-3' & & \\
\hline GplOXA66F89 & 5'-GCGCTTCAAAATCTGATGTA-3' & \multirow[t]{3}{*}{559} & \\
\hline GplOXA66R647 & 5'-GCGTATATTTTGTTTCCATTC-3' & & \\
\hline \multicolumn{2}{|r|}{ Multiplex 2} & & \\
\hline Group2ompAF378 & 5'-GACCTTTCTTATCACAACGA-3' & \multirow[t]{2}{*}{343} & \\
\hline Groupland2ompAR660 & 5'-CAACTTTAGCGATTTCTGG-3' & & \\
\hline Group2csuEF & 5'-GGCGAACATGACCTATTT-3' & \multirow[t]{2}{*}{580} & \\
\hline Group2csuER & 5'-CTTCATGGCTCGTTGGTT-3' & & \\
\hline Gp2OXA69F169 & 5'-CATCAAGGTCAAACTCAA-3' & \multirow[t]{2}{*}{162} & \\
\hline Gp2OXA69R330 & 5'-TAGCCTTTTTTCCCCATC-3' & & \\
\hline
\end{tabular}

Tabel 4

PRIMERS USED IN THE IDENTIFICATION OF THE GLOBAL LINEAGES OF THE STRAINS - $A$. baumannii

\section{Results and discussions}

The antibiotic resistance profiles in $\mathrm{H}$ and $\mathrm{CA} A$. baumannii isolates revealed high percentages of carbapenem-resistance in both $\mathrm{H}$ and $\mathrm{CA}$ isolates, i.e. imipenem (82.66\%/77.77\%), meropenem (84\%/83.33\%) as well as for SXT (85.33\%/77.77\%) and aminoglycosides (85.33\%/66.66\%). The ciprofloxacin resistance was closed in both types of isolates (84\%/83.33\%) (fig. 1). A. baumannii has acquired a huge genetic repertoire via horizontal gene transfer that makes it virulent and resistant to any environmental pressures [30-33]. Antibiotic susceptibility testing in this study showed that all $A$. baumannii isolates were resistant to the commercially available antibiotics with the exception of colistin. Previously in Romania, Vaduva et al., revealed the presence of beta-lactamase producers nosocomial $A$. baumannii strains from Timisoara hospital and a very closer aminoglycosides resistance profile [34].

CRAB $\mathrm{H}$ and $\mathrm{CA}$ isolates revealed the intrinsec carbapenemase OXA-51(58.6\%/55.5\%) and the acquired 

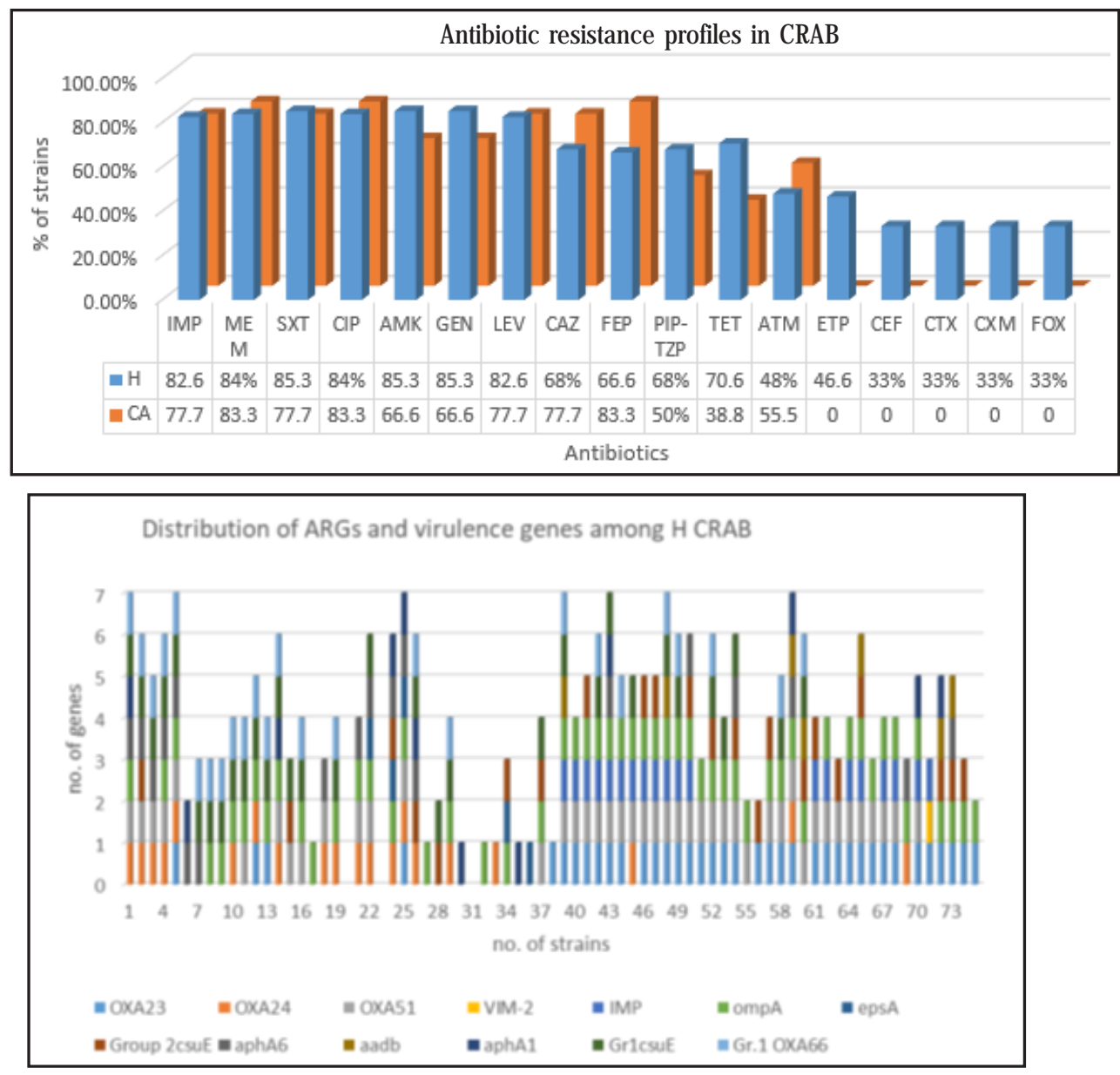

Fig. 1. Graphic representation of antibiotic resistance profiles (\%) in analysed CRAB strains
Fig. 2. Graphic representation of antibiotic resistance and virulence genes in analysed $\mathrm{H}$ strains

Distribution of ARGs and virulence genes among CA isolates

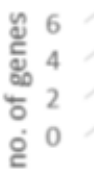

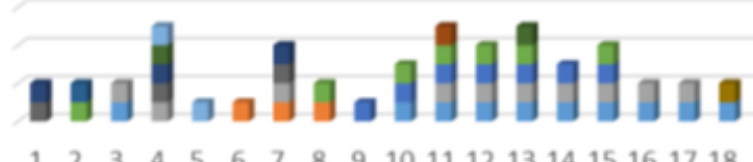

no. of strains

$$
\begin{aligned}
& \text { mOXA23 }=\text { OXA24 }=\text { OXA51 }=\text { VIM-2 }
\end{aligned}
$$

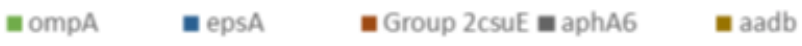

$$
\begin{aligned}
& \text { maphA1 } \mathbf{m} \text { GricsuE }=\text { Gr.1 OXA66 }
\end{aligned}
$$

carbapenemases OXA-23 (50\%/55.5\%), OXA-24 (26.6\%/ 16.6\%) IMP (26.66\%/22.22\%) and VIM-2 (1.33\%/0\%) (fig. $2,3)$.

In Bucharest, one study performed on $A$. baumannii nosocomial strains recovered from clinical infections in patients hospitalized in ICU between 2001-2003 demonstrated the association of class 1 integrons with

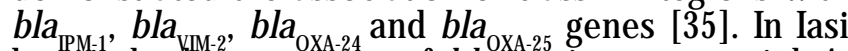
hospitals the presence of blaX-25 in nosocomial $A$. baumannii strains was revealed [36]. Data revealed by our research team (2012-2013) demonstrated that $A$. baumannii strains that were investigated harboured the class D carbapenemase OXA-23 [37]. Previous studies in Timisoara, Arad and Resita indicated that CHLD in A. baumannii is encoded by chromosomally - located bla $a_{\text {XX.23, }}$ with the insertion sequence ISAbaI detected upstream and the strains belonged to the ST2 and ST1 clones [6]. More recently one study from our department highlights a remarkable mobility for bla $a_{0 \times A-23}-T n 2008$ and surrounding structures (identified in plasmid or chromosome of different clones) and also describes for the first time the spread of Tnaph6-carrying pACICU2-like plasmids in A. baumannii in Europe [27]. A pilot study from three Romanian hospitals - lasi and Targu-Mures (20142015) demonstrated the presence of carbapenemases OXA-23, OXA-24/72 in $A$. baumannii nosocomial isolates [38].

Mammina et al., in 2012 revealed the presence in a high percentage of bla $a_{\text {XX.23 }}$ gene in nosocomial CRAB isolated ICU patients in Palermo Italy and belonging to ST2 [39].

Very recently Petrova et al., demonstrated a higher prevalence of OXA-23 A. baumanniiproducers isolated from different Bulgarian hospitals between 2010-2014 but opposite with our results they didn't observe the presence of OXA-24 and overexpression of OXA-51 in any of the analysed isolates [40].

In our study bla ${ }_{\text {xxa-zz }}$ gene was identified in different plasmid types (GR2-Áci1, GR6-pACICU2). rep135040 


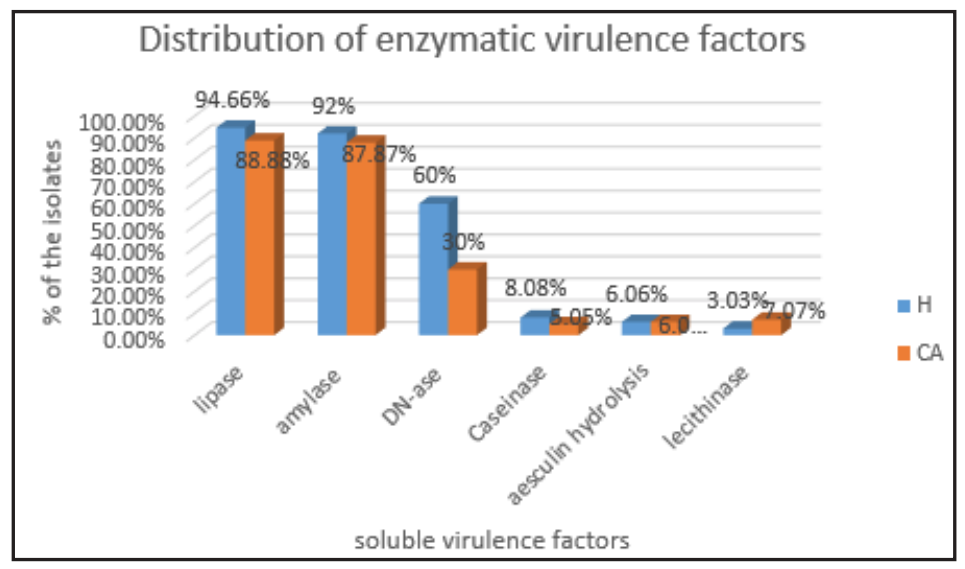

Fig. 4. Graphic representation of enzymatic virulence factors production in CRAB isolates.
(100\%) and p3S18 (100\%), followed by Aci6 (67\%) in $\mathrm{H} \mathrm{A.}$ baumannii isolates.

The multidrug resistant profile of the isolates was also heightened by the presence of AME's namely the phosphotransferase AphA6 (24\%/16.6\% of the strains), AphA1 (16\%/16.6\%) and acetyltransferases aadB (9.3\%) $5.5 \%$ ). Nowak etal., in 2014 reported in MDR A. baumannii isolated in Poland the following aminoglycoside resistance genes: aphA1, aphA6,and aacC1 [41]. The genes encoding AMEs can be disseminated via integrons, and expression of AMEs enable bacteria to catalyze the modification of amino and hydroxyl groups on sugar moieties, such as aminoglycosides [42].

Carbapenem and aminoglycosides resistance has been associated to nonenzymatic mechanisms revealed by changes on the outer membrane proteins [ompA biofilmproducing virulence factor $(66.66 \%$ of the analysed strains)], mechanism [43] demonstrated also by different authors. The outer membrane protein $A$ of $A$. baumannii represent one of the most abundant surface protein associated with the apoptosis of epithelial cells through mitochondrial targeting [44]. OmpA is also the major nonspecific channel in $A$. baumannii and appears to be essential for this organism's high levels of intrinsic resistance to different antibiotics [45]. Several reports have been demonstrated that $A$. baumannii possesses Omp's which interfere with carbapenem resistance, for e.g. in 2002, Limansky et al. demonstrated that imipenem resistance was associated with the loss of a 29-kDa Omp in clinical isolates of $A$. baumannii in which no carbapenemase activity had been detected [46].

Regarding the soluble virulence factors, the decreasing frequently expressed were lipase $(94.66 \% / 88.88 \%)$, amylase $(92 \% / 87.87 \%)$, DN-ase $(60 \% / 30 \%)$, caseinase $(8.08 \% / 5.05 \%)$; aesculin hydrolysis $(6.06 \% / 6.06 \%)$ and lecithinase (3.03\%/7.07\%) (Fig. 4).

OXA-51-like alleles corresponding to the two main sequence groups were identified as bla ${ }_{\text {ox }}(63.63 \%$ of the isolates) and respectively, bla revealed the corresponding type of OMpA and csuE sequence grouping (fig. 2, 3). There have been revealed a link between the production of some of the naturally occurring OXA-51/69-like oxacillinases and carbapenem resistance in $A$. baumannii. Despite the relatively weak ability of these enzymes to hydrolyse carbapenems, it has been shown that these oxacillinases may sometimes be overexpressed, resulting in a decreased level of susceptibility to carbapenems and the presence of ISAbalelement upstream of the bla OxA-51/69 -like gene (J. Turton, N. Woodford and T. Pitt, personal communication).

\section{Conclusions}

The significant levels of antibiotic resistance in CRAB strains highlights the need for continuous surveillance and epidemiological studies, of not only hospital, but also CA isolates. The elucidation of the genetic context of resistance in CRAB isolates with different origins could reveal further clinically important associations, and help to better understand the interaction between antimicrobial resistance and virulence in A.baumannii.

Acknowledgments: The financial support of the Research Projects PN-III-P1.1-PD-2016-1798 (PD 148/2018) awarded by UEFISCDI and Research grant for young researchers no. 27/2017 (28542) awarded by ICUB is gratefully acknowledged.

\section{Abbreviation \\ CRAB - Carbapenem Resistant Acinetobacter baumannii \\ AMEs - aminoglycoside-modifying enzymes \\ $\mathrm{H}$ - hospitalized patients \\ CA - Community acquired infections}

\section{References}

1. LEMOS, E.V., DE LA HOZ, F.P., EINARSON, T.R., MCGHAN, W.F., QUEVEDO, F., CASTANEDA, C. 2014. Clinical Microbiology and Infection, 20, 2014, p. 416-423.

2. MAGIORAKOS, A.P., SRINIVASAN, A., CAREY, R.B., CARMELI Y., FALAGAS, M.E., GISKE, C.G., HARBARTH, S., HINDLER, J.F., KAHLMETER, G., OLSSON-LILJ EQUIST, B., PATERSON, D.L., RICE, L.B., STELLING J ., STRUELENS, M.J ., VATOPOULOS, A., WEBER, J.T., MONNET, D.L. ClinMicrobiol Infect. 18, no. 3, 2012, p. 268-81.

3. DA SILVA, G.J., DOMINGUES, S. Microorganisms, 4, no. 29, 2016, DOI:10.3390/microorganisms4030029.

4. MUGNIER, P., POIREL, L., NAAS, T., NORDMANN, P. Emerging Infections Diseases, 16, no. 1, 2010, p. 35-40.

5. SENKYRIKOVA, M., HUSICKOVA, V., CHROMA, M., SAUER, P., BARDON, J., KOLAR, M. Springer Plus, 2, 2013, p. 296.

6. BONNIN, R.A., POIREL, L., LICKER, M., NORDMANN, P. Clinical Microbiology and Infection, 17, no.10, 2011, p. 1524-1528.

7. POIREL, L., NORDMANN, P. Clin Microbiol Infect, 12, 2006, p. 826836.

8. PELEG, A.Y., SEIFERT, H., PATERSON, D.L. Clin Microbiol Rev, 21, 2008, p. 538-582.

9. KARAH, N, SUNDSFJ ORD, A, TOWNER, K, SAMUELSEN, O. Drug Resist Updat, 15, 2012, p. 237-247.

10.NEMEC, A, DOLZANI，L，BRISSE，S, VANDEN BROEK, P, DIJ KSHOORN, L. J Med Microbiol, 53, 2004, p.1233-1240.

11. TOMARAS, A.P., DORSEY, C.W., EDELMANN, R.E., ACTIS, L.A. Microbiology, 149, 2003, p. 3473-3484.

12. NIU, C., CLEMMER, K.M., BONOMO, R.A., RATHER, P.N. J . Bacteriol. 190, 2008, p. 3386-3392. 
13. SCHWEPPE, D.K., HARDING, C., CHAVEZ, J.D., WU, X., RAMAGE, E., SINGH, P.K., MANOIL, C., BRUCE, J.E. Chem Biol, 22, 2015, p. 15211530.

14. LONGO, F., VUOTTO, C., DONELLI, G. New Microbiologica, 37, 2014, p. 119-127.

15. CAMARENA, L., BRUNO, V., EUSKIRCHEN, G., POGGIO, S., SNYDER, M. PLoS Pathog, 6, 2010, e1000834.

16. JACOBS, A.C., HOOD, I., BOYD, K.L., OLSON, P.D., MORRISON, J.M., CARSON, S., SAYOOD, K., IWEN, P.C., SKAAR, E.P., DUNMAN, P.M. Infect Immun, 78, 2010, p. 1952-1962.

17. GADDY, J.A., ARIVETT, B.A., MCCONNELL, M.J ., LOPEZ-ROJAS, R., PACHON, J., ACTIS, L.A. Infect Immun, 80, 2012, p. 1015-1024.

18. RUSSO, T.A., LUKE, N.R., BEANAN, J.M., OLSON, R., SAUBERAN, S.L., MACDONALD, U., SCHULTZ, L.W., UMLAND, T.C., CAMPAGNARI, A.A. Infect Immun,78, 2010, p. 3993-4000.

19. RUSSO, T.A., MACDONALD, U., BEANAN, J.M., OLSON, R., MACDONALD, I.J ., SAUBERAN, S.L., LUKE, N.R., SCHULTZ, L.W., UMLAND, T.C. J Infect Dis, 199, 2009, p. 513-521.

20. JACOBS, A.C., SAYOOD, K., OLMSTED, S.B., BLANCHARD, C.E., HINRICHS, S., RUSSELL, D., DUNMAN, P.M. FEMS Immunol Med Microbiol, 64, 2012, p. 403-412.

21. DAHDOUH, E., GOÂMEZ-GIL, R., PACHO, S., MINGORANCE, J., DAOUD, Z., SUAREZ, M. PLOS ONE, 12, no. 4, 2017, e0176824.

22. FALAGAS, M.E., BLIZIOTIS, I.A., SIEMPOS, I.I. Crit Care, 10, no. 2, 2006, R48.

23. ANSTEY, N.M., CURRIE, B.J ., HASSELL, M., PALMER, D., DWYER, B., SEIFERT, H. J Clin Microbiol 40, no. 2, 2002, p. 685-686.

24. WOODFORD, N., ELLINGTON, M.J ., COELHO, J.M., TURTON, J.F., WARD, M.E., BROWN, S et al. Int] Antimicrob Agents. 27, no. 4, 2006, p. 351-353.

25. BOGAERTS, P., REZENDE, DE CASTRO, R DE MENDONCA, HUANG, T-H., DENIS, Q., GLUPCZYNSKI, Y. 2013. J ournal of Antimicrob Chemother, 68, 2013, p. 1576-1582.

26. HANDAL, R., QUNIBI, L., SAHOURI, I., JUHARI, M., DAWODI, R., MARZOUQA, H., HINDIYEH, M. Internat. Journal of Microbiol, 2017, p. 1-7, https://doi.org/10.1155/2017/8012104.

27. GHEORGHE, I., NOVAIS, A., GROSSO, F., CHIFIRIUC, M.C., LAZAR, V., PEIXE, L. J Antimicrob Chemother, 70, no. 4, p. 1016-20.

28. BERTINI, A., POIREL, L., MUGNIER, P.D., VILLA, L., NORDMANN, P., CARATTOLI, A. Antimicrobial Agents and Chemotherapy. 54, no. 10, 2010, p. 4168-4177.

29. TURTON, J.F., GABRIE, S.N., VALDERREY, C., KAUFMANN, M.E., PITT, T.L. Clinical Microbiology and Infection, 13, no. 8, 2007, 10.1111/ j.1469-0691.2007.01759.x.
30. MUNOZ-PRICE, L.S., WEINSTEIN, R.A. The New England Journal of Medicine, 358, no.12, 2008, p. 1214-1281.

31. PEREZ, F., HUJER, A.M., HUJER, K.M., DECKER, B.K., RATHER, P.N., BONOMO, R.A. Antimicrob Agents and Chemother, 51, no.10, 2007, p. 3471-3484.

32. CAI, Y., CHAI, D., WANG, R., LIANG, B., BAl, N. J ournal of Antimicrob Chemother, 67, no. 7, 2012, p. 1607-1615.

33. FOURNIER, P.E., VALLENET, D., BARBE, V., et al. PLoS Genetics, 2, 2006, p. 1.

34.VADUVA, D.B., MUNTEAN, D., LONESCU, G., LICKER, M., VADUVA, M.B., VELIMIROVICI, D., RADULESCU, M., DUMITRASCU, V., CRACIUNESCU, M., DUGaESESCU, D., HORHAT, F., PILUP, C., BADITOIU, L., MOLDOVAN, R. Bacteriol Virusol Parazitol Epidemiol. 53, no. 2, 2008, p. 103-7.

35. RADU-POPESCU, M.A., DUMITRIU, S., ENACHE-SOARE S., BANCESCU, G., UDRISTOIU, A., COJ OCARU, M., VAGU, C. Farmacia, 3, 2010, p. 362-367.

36. MEREUTA, A.I., BADESCU, A.C., DOMEANU, O.S., IANCU, L.S., TUCHILUS, C.G. Rev Rom De Med De Laborator, 21, no. 4, 2013, p. 423-30.

37. GHEORGHE, I., CZOBOR, I., CHIFIRIUC, M.C., BORCAN, E., GHITA, C., BANU, O., LAZAR, V., MIHAESCU, G., MIHAILESCU, D.F., ZHIYONG, Z. J Med Microbiol, 63, 2014, p. 1303-1310.

38. TIMOFTE, D., PANZARU, C.V., MACIUCA, I.E. Eurosurveillance. 21, no. 25, 2016, pii=30262. DOI: http://dx.doi.org/10.2807/1560-7917.

39. MAMMINA, C., PALMA, D.M., BONURA, C., ALEO, A., et al. Folia Medica. 59, no. 4, 2017.

41. NOWAK, P., PALUCHOWSKA, P.M., BUDAK, A. Medical science monitor basic research. 20, no. 9, 2014, p.14.

42. TOWNER, KJ. J Hosp Infect. 73, 2009, p. 355-63.

43. DEL MAR TOMAS, M., BECEIRO, A., PÉREZ, A., et al. Journal of Antimicrob Chemother, 49, 2005, p. 5172-5175.

44. CHOI, C.H., HYUN, S.H., LEE, J.Y., LEE, J.S., LEE, Y.S., KIM, S.A., CHAE, J.P., YOO, S.M., LEE, J.C. Cell Microbiol. 10, 2008, p. 309319.

45. SMANI, Y., FABREGA, A., ROCA, I., SANCHEZ-ENCINALES, V.S., VILA, J., PACHONA, J. Antimicrob Agents and Chemother. 58, no. 3, p. 1806- 1808.

46. LIMANSKY, A.S., MUSSI, M.A., VIALE, A.M. J Clin Microbiol. 40, 2002, p. 4776-4778.

Manuscript received: 29.06 .2018 